\title{
The Surgical Treatment of Tissue Necrosis due to Diclofenac Sodium Injection (Nicolau Syndrome)
}

\author{
Diklofenak Sodyum Ekjeksiyonuna Bağlı Doku Nekrozunun (Nicolau Sendromu) Cerrahi Tedavisi
}

\author{
Tolga AKSAN ${ }^{1}$ \\ (i) 0000-0002-3328-2652 \\ Ŭ̆ur Kaan KALEM ${ }^{1}$ \\ (10) 0000-0002-6291-3978 \\ Muhammed Beşir ÖZTÜRK ${ }^{1}$ \\ (1) 0000-0002-8977-3741 \\ Cengiz ERTEKIN ${ }^{1}$ \\ (D) 0000-0003-4610-3219 \\ Korhan ÖZKAN ${ }^{2}$ \\ (D) 0000-0002-3755-1813
}

\begin{abstract}
Aim: Nicolau syndrome (NS) is the necrosis of skin and subcuticular tissue, following injection of many drugs, which covers nearly a perforasome. This study aims to unveil our clinical approach and treatment alternatives against this rare pathology subsequent to diclofenac sodium.

Material and Methods: In this retrospective study, our approach to 16 patients who developed NS at the injection site after diclofenac sodium injection was evaluated. Patients' demographic data, concomitant diseases, location and size of necrosis, and surgical techniques were collected. Post-operative complications, hospitalization period and results were evaluated.

Results: There were total of 16 patients, 2 of which were male and 14 were female. The mean age was $60 \pm 14.4$ years, and the mean body mass index (BMI) was $33 \pm 1.4 \mathrm{~kg} / \mathrm{m}^{2}$. The major concomitant comorbidity was diabetes mellitus, followed by primary hypertension. The mean defect size was $8 \times 8 \times 5 \mathrm{~cm}$. Surgical debridement was applied to all 16 necrosis. Following the surgical debridement of necrosis, 8 patients were reconstructed with primary closure, 6 patients with fasciocutaneous flaps and 2 patients with delayed primary closure after a week. All patients heal completely without complications.

Conclusion: Utmost care must be given when performing diclofenac sodium injections to the patients with comorbidities, such as high BMI, diabetes mellitus, and primary hypertension. The caregiver must be certain that the needle is in the muscular plane and no perforator vessel to be harmed during this procedure. In case of a post-injection necrosis, an early intervention with surgical debridement and reconstruction is an efficient treatment.

Keywords: Diclofenac sodium; injection; intramuscular; Nicolau syndrome.
\end{abstract}

\section{ÖZ}

Amaç: Nicolau sendromu (NS), bazı ilaçların enjeksiyonlarını takiben gelişen ve yaklaşık bir perforazomu kaplayan boyutlara ulaşan yumuşak doku ve ciltte nekroz gelişmesi durumudur. $\mathrm{Bu}$ çalışmada klinikte sık karşılaşılmayan diklofenak sodyum enjeksiyonu sonrası gelişmiş bu nadir patolojiye yönelik klinik yaklaşımımız ve tedavi alternatiflerinin sunulması amaçlanmıştır.

Gereç ve Yöntemler: Bu geriye dönük çalışmada diklofenak sodyum enjeksiyonu sonrası enjeksiyon yerinde NS gelişen 16 hastaya yaklaşımımız değerlendirildi. Hastaların demografik verileri, eşlik eden hastalıkları, nekrozun yerleşimi ve boyutları ve cerrahi teknikler tarandı. Postoperatif komplikasyonlar, hastanede kalış süresi ve sonuçlar değerlendirildi.

Bulgular: Toplam 16 hasta mevcut olup bunların 14'ü kadın 2'si erkek idi. Ortalama yaş $60 \pm 14,4$ yıl ve ortalama vücut kitle indeksi (VKI) $33 \pm 1,4 \mathrm{~kg} / \mathrm{m}^{2}$ idi. En sık eşlik eden hastalık diyabetes mellitus, daha sonra primer hipertansiyon olarak gözlendi. Ortalama nekroz boyutu $8 \times 8 \times 5 \mathrm{~cm}$ olarak saptandi. Tüm 16 nekroza da cerrahi debridman uygulandi. Nekrozun cerrahi debridmanı sonrası 8 hastanın defekti primer kapatılırken 6 hastada fasyokutan flep yapıld 1 ve 2 hasta ise bir hafta sonra gecikmiş primer olarak onarıldı. Hastaların tümü sorunsuz olarak tamamen iyileşti.

Sonuç: Yüksek VKİ, diyabetes mellitus ve primer hipertansiyon gibi komorbid özellikler taşıyan hastalara diklofenak sodyum enjeksiyonu yapılırken çok dikkatli olunmalıdır. İşlem sırasında, iğnenin kas tabakasına kadar ulaştığından ve perforatör bir damara denk gelmediğinden emin olunmalıdır. Enjeksiyon sonrası nekroz gelişmesi durumunda erken dönemde cerrahi debridmanı takiben rekonstrüksiyon etkili bir tedavidir.

Accepted / Kabul Tarihi : 29.11.2020 Available Online /

Anahtar kelimeler: Diklofenak sodyum; enjeksiyon; intramüsküler; Nicolau sendromu. 


\section{INTRODUCTION}

Although it usually occurs after intramuscular injections, the Nicolau syndrome (NS) is a rare reaction, which may end up with the formation of a livedoid dermatitis-like necrotic defect rarely emerging after subcutaneous or intravenous injections (1). This pathologic state which was initially recorded upon injection of bismuth salts, ends up with a necrosis of the skin, the subcutaneous tissues, and even sometimes within the musculature. It is often attributed to the injection of NSAIDs, but it may also happen with local anesthesia, penicillin, and vitamin K (2). Although the mechanism behind this pathology is not clear, fat necrosis and local cyclooxygenase (COX) inhibition are believed to be the reason behind it (3). According to the literature, the common surgical approach towards NS cases comprises reconstruction of the harmed tissue following an adequate debridement. In this study we aimed to present our plastic surgery approach towards NS, based on 16 cases who treated in our clinic.

\section{MATERIAL AND METHODS}

Upon approval of the Istanbul Medeniyet University Clinical Research Ethics Committee (2020/0406), 16 NS cases had been detected which have been treated at our institution and retrospectively analyzed between the years of 2016 and 2020. All cases were patients who received intramuscular diclofenac sodium injections at different parts of the body. The demographics, body mass indexes (BMIs), pre-injection medical conditions, comorbidities, defect areas, preoperative-intraoperative and postoperative photographs of patients and their follow-up data were examined.

\section{Surgical Technique}

All patients except one patient (general anesthesia) was operated under spinal anesthesia and 1 gr of cephazoline sodium (intravenous) was prophylactically given to each one, an hour prior to the operation. Necrotic tissues were debrided above muscular fascia until yellow colored healthy fat tissue was observed. Deep tissue biopsy samples were also taken. Upon completion of debridement and irrigation, the depth and the surface area of the defect was measured and photographed. After debridement, if the defect is suitable for primary closure, the defect was sutured primarily (Figure 1). Defects that cannot be closed primarily were reconstructed with fasciocutaneous flaps (Figure 2). Two patients, who had an infected wound area that was not suitable for an immediate surgical closure, were treated with negative pressure wound therapy (NPWT). No limitations were applied for patient mobilization after surgery. All patients were monitored with hemovac drains and changed dressing every two days in the post-operative period. The drains were held until the drainage amount less than $25 \mathrm{cc} /$ day. The patients were discharged from the hospital after drainage tubes had been expelled. The patients received $3 \times 1$ gr intravenous cephazoline sodium within the day of operation, followed by oral amoxicillin-clavulanic acid $2 \times 1$ gr for a week.

\section{RESULTS}

Sixteen patients with NS were treated at our clinic between 2016 and 2020, 14 of which were female and 2 were male. The mean patient age was $60 \pm 14.4$ (range, $35-78$ ) years. All of the patients, except the one (who was 35 years old), had comorbidities. Diabetes mellitus was one of the most common $(n=10)$ comorbidities in the group, and primary hypertension $(\mathrm{n}=6)$ was the second. The average BMI was $33 \pm 1.4$ (range, $31.4-35.2) \mathrm{kg} / \mathrm{m}^{2}$ (Table 1 ).
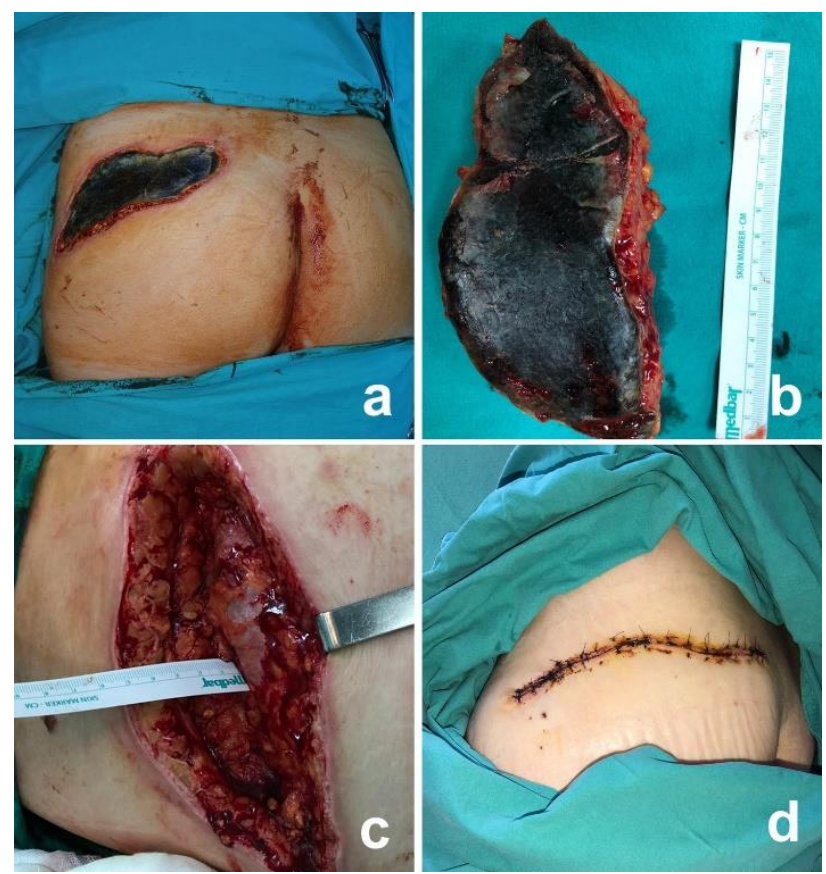

Figure 1. The necrosis on the left gluteal region 2 weeks after diclofenac sodium injection (a). The necrosis was debrided (b). The fat thickness was evaluated $5 \mathrm{~cm}$ after debridement (c). Postoperative $1^{\text {st }}$ week of the gluteal region after primary closure (d).
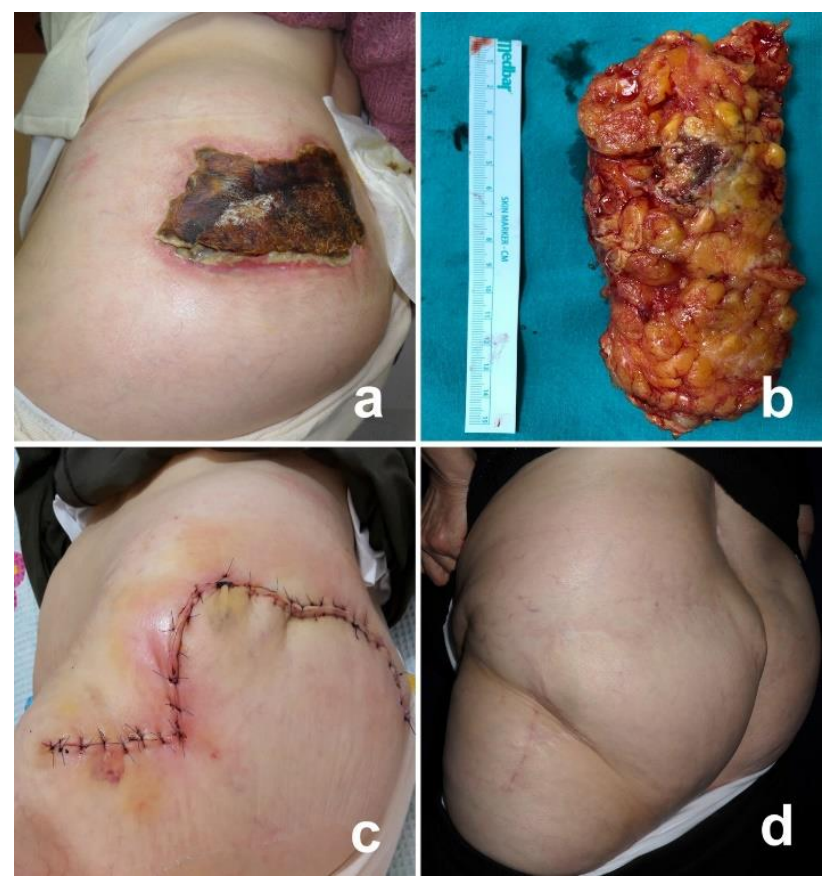

Figure 2. The necrosis on the left gluteal region 3 weeks after diclofenac sodium injection (a). The necrosis was debrided (b). The defect was reconstructed with a fasciocutaneous rotation flap (c). Patient at postoperative $6^{\text {th }}$ month (d). 
Intramuscular diclofenac sodium injection was the sole reason for the necrosis in our patient group. The location of necrosis varied by patient; 5 patient at the right gluteal, 6 patient at the left gluteal, 4 patient at the left thigh lateral border and 1 patient, who ignorantly self-injected herself, at the periumbilical region. The patients were operated at an average of 5 (2-9) weeks after the injection. As the necrosis depths were examined intraoperatively, it was observed that necrosis had reached to the deep fascia but the musculature was not harmed. The largest area of necrosis was $10 \times 20 \times 4 \mathrm{~cm}$, and the smallest was $2 \times 2 \times 4 \mathrm{~cm}$ (average $8 \times 8 \times 5 \mathrm{~cm}$ ). The defects of 8 patients were treated with primary closure. Six patients were reconstructed with rotational fasciocutaneous flaps. Two patients, who had an infected defect base and also had a pouche larger than the necrosis area, was treated with a NPWT device for two sessions (3 days for each session). After a week, an effective contraction had occurred at the defect, thus it was reconstructed with delayed primary closure. The average operation time was 64 (range, 30-95) minutes. No postoperative complications observed. The patients were hospitalized at an average of 5.1 (range, 2-10) days. The mean follow up period was 11.7 (range, 6-14) months. According to the wound cultures that were sampled in the operation, 2 patients had E. coli, 4 patients had normal skin flora, and the rest showed negative results. The culture positive cases were all amoxicillin susceptive, thus no antibiotic therapy changes had occurred.

\section{DISCUSSION}

Nicolau Syndrome is an acute and destructive condition after injections. It was first described and named by Dr. Stefan Nicolau in 1925. Although he described this syndrome as a result of arterial damage in his study, there have been many theories on the pathophysiological pathway (4). This pathology seems to occur most frequently after NSAID injections (3), however that the necrosis may also be seen after penicillin, vitamin $\mathrm{K}$,

Table 1. Patient demographics and clinical progression

\begin{tabular}{lc}
\hline Gender, $\mathrm{n}(\%)$ & $2(12.5)$ \\
$\quad$ Male & $14(87.5)$ \\
$\quad$ Female & $60 \pm 14.4(35-78)$ \\
Age (years), mean $\pm \mathrm{SD}$ & $33 \pm 1.4(31.4-35.2)$ \\
Body mass index $\left(\mathrm{kg} / \mathrm{m}^{2}\right)$, mean $\pm \mathrm{SD}$ & \\
Comorbidities, $\mathrm{n}(\%)$ & $6(37.5)$ \\
$\quad$ Primary Hypertension & $10(62.5)$ \\
$\quad$ Diabetes Mellitus & $2(12.5)$ \\
$\quad$ Hypothyroidism & \\
Necrosis Localization, $\mathrm{n}(\%)$ & $11(68.8)$ \\
$\quad$ Gluteal region & $4(25.0)$ \\
$\quad$ Tight & $1(6.2)$ \\
$\quad$ Periumbilical & $2 \times 2 \times 4$ \\
Defect size (cm) & $10 \times 20 \times 4$ \\
$\quad$ Minimum & $8 \times 8 \times 5$ \\
$\quad$ Maximum & \\
Mean & $8(50.0)$ \\
Surgical Treatment, $\mathrm{n}(\%)$ & $6(37.5)$ \\
$\quad$ Debridement + Primary repair & \\
$\quad$ Debridement + Fasciocutaneous & \\
rotation flap & $2(12.5)$ \\
Primary reconstruction + NPWT + & \\
Delayed primary repair & \\
\hline SD: standard deviation, NPWT: negative pressure wound therapy
\end{tabular}

thiocolchicosid, lidocaine, naltrexone, DPT vaccine and mesotherapy injections (5-7). Ezzedine et al. (8) suggest diclofenac, as a potent cox inhibitor - thus inhibiting prostaglandin synthesis, increases the formation of necrosis. Another theory suggests that perineural, intraarterial, and periarterial injections cause local pain, and vasospasm secondary to the local pain leads to sympathetic nerve stimulation followed by necrosis $(6,9)$. NS rises to the occasion with pain and erythema and they are followed by the bullous lesions and tissue necrosis (10). Necrosis may not be limited to subcutaneous adipose tissue. In the literature, extensive damage to deep muscle tissue and even limb losses due to ischemia of the whole limb have been reported (4,11). Saputo and Bruni (12) reported that 80 of their 102 cases were under the age 12. They suggested that any small arterial diameter has a tendency to build up thrombosis, which leads to the tissue necrosis. Nonetheless, our study group composed of only adults (a mean of 60 years), making their suggestion contradictory. Furthermore, the irritative features of the injection materials are thought to cause abscess and necrosis (13).

Some medical treatments have been defined to treat NS, such as heparin, topical betamethazone, and vasoactive agents (14). We have our reasons to believe that early surgical intervention is more advantageous for these patients, since the etiology is not clear, patients' appeal for medical attention is late, and most importantly the general medical condition of these patients is not suitable for a long-lasting hospitalization.

As one can see from all of the cases, our clinical approach to NS was surgical, that is, debridement and reconstruction of the wound according to the plastic surgery basic principles. The basic difference between primary versus flap reconstruction was the size of the necrosis. In the primary reconstruction group the mean defect size was $4.25 \times 3.5 \times 4.25 \mathrm{~cm}$. This mean size was calculated as $11.25 \times 12.25 \times 5.25 \mathrm{~cm}$ in the flap reconstruction group. Kocman et al. (15) put forward the free style perforator flaps for reconstruction of the gluteal region. They believe their technique offers better aesthetic results. However, a perforator flap requires meticulous dissection of the pedicle, thus extending the operation time. Owing to the fact that we reconstructed our patients either primary closure or with fasciocutaneous flaps, our average operation time was 64 minutes, making our intervention significantly shorter. When we consider the patients with multiple comorbidities, this result gains importance. Furthermore, none of our patients experienced postoperative complications. In addition to its safety, long term aesthetic results were pretty satisfactory, which takes our technique one step ahead.

When the defects were observed, the average depth was $4.75 \mathrm{~cm}(4-6 \mathrm{~cm})$, being deeper than an ordinary green 21 Gauge needle, which is $3.8 \mathrm{~cm}$ long. The basic problem here might be the injection into a superficial plane rather than muscle, such as the fat tissue, which has a scarce vascular support. Our group was constituted by obese patients, supporting the latter proposition. Dadac1 et al. (16) did find similar results in their own research. NSAIDs, such as diclofenac sodium, may cause cytotoxic effects by altering local $\mathrm{pH}$ levels and activating the preapoptotic pathways. Therefore, even a proper injection inside the musculature may cause local destruction $(6,17,18)$. On the 
other hand, the necrosis mimics a perforasome as its demarcation line passes over the injection area. The basic pathology here might be the injury of the arterial plexus at the hypodermal level by the injected agent, causing embolization of the perforators nourishing the skin, leading a perforasome-like necrosis area.

There is still no preventive method against NS development. The Lesser technique that is used for IM injections seems inadequate (19). This technique emphasizes to aspirate first when the needle is at the desired plane, then to inject in order not to damage any vasculature. In order to prevent NS, a modified version of the above explained technique can be used, the "Z-shaped Injection". In this technique the skin and subdermal contents are pushed downwards with the nondominant hand, thus reducing the distance between the skin and the muscular plane, thereupon increasing the possibility to inject the drug into the muscle. The needle is inserted at angle of 90 degrees and aspirated for at least 5 seconds before injecting the drug. A maximum of $5 \mathrm{ml}$ is injected at a single time. The needle exits all tissues at an angle of 90 degrees. By this way, the drug leakage to subcutaneous tissues is prevented (20).

\section{CONCLUSION}

There is still no proven method to prevent NS development, however, injecting with the Z-shaped technique, using a longer needle in obese patients, and choosing different injection locations (deltoid, thigh, etc.) in selected patients possibly lessen the frequency of tissue necrosis. Another option is to be aware of this pathology and prescribe drugs per oral in suitable patients. There isn't any unique way to cure NS when it is developed, but early recognition, aggressive surgical debridement and reconstruction offers an efficient treatment and a rapid recovery.

Ethics Committee Approval: The study was approved by the Ethics Committee of İstanbul Medeniyet University Faculty of Medicine (24.06.2020, 0406).

Conflict of Interest: None declared by the authors.

Financial Disclosure: None declared by the authors.

Acknowledgements: None declared by the authors.

\section{REFERENCES}

1. Nischal K, Basavaraj H, Swaroop M, Agrawal D, Sathyanarayana B, Umashankar N. Nicolau syndrome: an iatrogenic cutaneous necrosis. J Cutan Aesthet Surg. 2009;2(2):92-5.

2. Senel E. Nicolau syndrome as an avoidable complication. J Family Community Med. 2012;19(1):52-3.

3. Kılıç I, Kaya F, Özdemir AT, Demirel T, Çelik İ. Nicolau syndrome due to diclofenac sodium (Voltaren) injection: a case report. J Med Case Rep. 2014;8:404.

4. Lardelli PF, Jermini LMM, Milani GP, Peeters GGAM, Ramelli GP, Zgraggen L, et al. Nicolau syndrome caused by non-steroidal anti-inflammatory drugs: Systematic literature review. Int J Clin Pract. 2020;74(10):e13567.

5. Kim KK, Chae DS. Nicolau syndrome: a literature review. World J Dermatol. 2015;4(2):103-7.

6. Yeniocak A, Kelahmetoğlu O, Özkan M, Temel M, Güneren E. A basic algorithmic surgical approach for Nicolau syndrome. J Cutan Aesthet Surg. 2020;13(2):154-9.

7. Malik MH, Heaton H, Sloan B. Nicolau syndrome following intramuscular naltrexone injection. Dermatol Online J. 2020;26(7):13030/qt3gb5m0vr.

8. Ezzedine K, Vadoud-Seyedi J, Heenen M. Nicolau syndrome following diclofenac administration. $\mathrm{Br} \mathrm{J}$ Dermatol. 2004;150(2):385-7.

9. Senel E. Nicolau syndrome as an avoidable complication. J Fam Community Med. 2012;19(1):523.

10. Guarneri C, Polimeni G. Nicolau syndrome following etanercept administration. Am J Clin Dermatol. 2010;11(Suppl 1):51-2.

11. Zargarbashi R, Panjavi B, Keshavarz-Fathi M. Extensive deep tissue involvement in Nicolau syndrome and below-knee amputation: A case report and literature review. Int $\mathbf{J}$ Low Extrem Wounds. 2020; [Epub ahead of print]. doi: 10.1177/1534734620948768.

12. Saputo V, Bruni G. Nicolau syndrome caused by penicillin preparations: review of the literature in search for potential risk factors. Pediatr Med Chir. 1998;20(2):105-23.

13. Taylan Filinte G, Akan M, Filinte D, Gönüllü ME, Aköz T. Gluteal injections: As harmless as we think? Case report. South Clin Ist Euras. 2010;21(2):89-93.

14. Murthy SC, Siddalingappa K, Suresh T. Nicolau's syndrome following diclofenac administration: A report of two cases. Indian J Dermatol Venereol Leprol. 2007;73(6):429-31.

15. Kocman EA, Yaşar FN, Kose AA, Cil Y, Karabagli Y, Çetin C. Freestyle perforator-based fasciocutaneous flap reconstruction in Nicolau syndrome-related tissue necrosis. Indian J Surg. 2015;77(Suppl 3):1187-90.

16. Dadaci M, Altuntas Z, Ince B, Bilgen F, Tufekci O, Poyraz N. Nicolau syndrome after intramuscular injection of non-steroidal anti-inflammatory drugs (NSAID). Bosn J Basic Med Sci. 2015;15(1):57-60.

17. Probst M, Kühn JP, Modeß C, Scheuch E, Seidlitz A, Hosten $\mathrm{N}$, et al. Muscle injury after intramuscular administration of diclofenac: A case report supported by magnetic resonance imaging. Drug Saf Case Rep. 2017;4(1):7.

18. Aktas H, Yilmaz OE, Ertugrul G, Terzi E. Intramuscular diclofenac is a cause of Nicolau syndrome in obese women: An observational study of consecutive ten patients. Dermatol Ther. 2020;33(3):e13392.

19. Corazza M, Capozzi O, Virgilit A. Five cases of livedolike dermatitis (Nicolau's syndrome) due to bismuth salts and various other non-steroidal anti-inflammatory drugs. J Eur Acad Dermatol Venereol. 2001;15(6):585-8.

20. Pullen RL Jr. Administering medication by the Z-track method. Nursing. 2005;35(7):24. 